Review Article

\title{
Antarctic Palaeoclimatic Reconstruction Using Ice Cores: Indian Initiatives During 2008-2016
}

\author{
MELOTH THAMBAN* \\ ESSO - National Centre for Antarctic and Ocean Research, Headland Sada, Goa 403 004, India
}

(Received on 06 June 2016; Accepted on 25 November 2016)

\begin{abstract}
Study of ice core proxy records provide one of the most direct and accurate method to study the Antarctic climate change beyond the instrumental limits. Understanding the Antarctic climate variability on millennial, centennial to decadal level is crucial to our knowledge on the role and response of Antarctic ice sheets to the global climate variability. The Indian ice core studies have made significant contributions to the understanding of Antarctic climate variability and the various factors involved. The proxy environmental parameters used include temporal variability of stable isotopes, trace metal chemistry, ionic composition, dust particulates, and microbial components that are indicators of environmental change in the coastal Antarctica. Ice core proxy based reconstruction revealed significant changes in Southern Hemispheric climate during the past several hundreds of years. The study also revealed the utility of shallow ice cores in reconstructing the past changes in major climatic modes like the El Niño Southern Oscillation (ENSO) and Southern Annular Mode (SAM).
\end{abstract}

Keywords: Palaeoclimate; Ice Core; El Niño Southern Oscillation; Southern Annular Mode; Antarctica

\section{Introduction}

The Antarctic climate system fluctuates widely on sub-annual to millennial time scales, in tandem with the global climate system. Since the time-series observations of climatic parameters were initiated only from the International Geophysical Year (1957-58), most of the instrumental records of Antarctic climate are only some decades old. Based on the available time series data, Antarctica seems to have undergone complex and significant temperature changes in recent decades (Turner et al., 2005 \& 2006). While the largest annual warming trends are found on the western and northern parts of the Antarctic Peninsula (e.g., $+0.56^{\circ} \mathrm{C}$ per decade at Faraday/Vernadsky station), many stations in East Antarctica and Amundsen-Scott Station at the South Pole in particular has shown a small cooling in the annual mean temperature of $-0.05^{\circ} \mathrm{C}$ per decade (Turner et al., 2009). Notwithstanding these studies to understand the climate change in Antarctica, the spatial and temporal complexity of Antarctic climate are still poorly understood because of the limited and short periods of observational and instrumental data.

The north-to-south distribution of surface pressure around Antarctica is subject to remarkable variability in the intensity of the meridional pressure gradient and its zonal location. Due to the circumpolar nature of this variation, it is called the Southern Annular Mode (SAM), which is the principal mode of variability in the atmospheric circulation of the southern extratropics and high latitudes (see Trenberth et al., 2007). The SAM has a zonally symmetric or annular structure, with synchronous anomalies of opposite sign in high latitudes and midlatitudes (Lefebvre et al., 2004). The El Niño Southern Oscillation (ENSO) on the other hand, is the farthest reaching climatic cycle on Earth on decadal and sub-decadal time scales, affecting even the Southern Hemisphere (see Bromwich et al., 2000). The ENSO signals can be identified in the physical and biological environment of the Antarctic, although some of the links are not very robust and there can be large differences in the extra-tropical response to near-identical events in the tropics (see Turner, 2004).

*Author for Correspondence: E-mail: meloth@ncaor.gov.in 
Analysis of ice core records offer one of the most direct and accurate method to study the Antarctic climate change beyond the instrumental limits (Schneider et al., 2006; Mayewski et al., 2009). Ice core records from polar regions present continuous and highly resolved long-term records of reliable information on major atmospheric parameters like temperature, composition and trace gases. Among the various proxy variables used, the stable isotope ratios of oxygen $\left(\delta^{18} \mathrm{O}\right)$ and hydrogen $(\delta \mathrm{D})$ offer the most critical information on the past changes in temperature. Owing to the differences in saturation vapour pressure and molecular diffusivity, isotopic fractionation takes place at each phase change of atmospheric water (Dansgaard, 1964). Since the heavy isotopes in precipitation decrease with the temperature of condensation, stable isotope ratios in ice cores provide quantitative proxy records of past temperature. However, factors such as temperature of the source from which moisture evaporated, subsequent cycles of condensation and evaporation, change in moisture source region and seasonality of precipitation make the interpretation of temperature from water isotopes difficult (Jouzel et al., 2003).

\section{Results and Discussion}

During 2008-2016, several ice cores have been studied. The ice core drilling was carried out using an electromechanical drill system (GeoTecs Ltd, Japan; Model: Type D-2) during the austral summers. The retrieved ice cores (upto $101 \mathrm{~m}$ deep; diameter 10 $\mathrm{cm})$ were cold-shipped and archived at the NCAOR cold room facility $\left(-20^{\circ} \mathrm{C}\right)$, until further processing in the laboratory. Processing of the ice core samples were carried out at the ice core processing facility at NCAOR. The ice core samples were first subsampled using custom-made bandsaw machines at the cold room $\left(-15^{\circ} \mathrm{C}\right)$ processing facility. Subsequently, the selected samples were manually decontaminated by removing the outer layer using microtome blades. Prior to analyses, samples were thawed at room temperature in a Class 100 clean room. Stable isotope ratios of the ice core samples were measured following standard methods using an 'Isoprime' (GV instruments) Isotope Ratio Mass Spectrometer (Naik et al., 2010 a). While two ice cores were extensively studied and published during this period, data from other cores under analysis and interpretation.
The ice core proxy based studies at revealed significant changes in Antarctic cryosphere and Southern Hemispheric climate during the past several hundreds of years (Laluraj et al., 2009, 2011 \& 2014; Naik et al., 2010 a \& b; Thamban et al., 2011a \&b, 2013; PAGES 2k Consortium, 2013; Rahaman et al., 2016).

\section{Palaeo-environmental Variability During the Past Five Centuries}

High-magnification SEM-EDS study of microparticles in the ice core of the $22^{\text {nd }}$ IAE core revealed that these particles are mostly derived from volcanic eruptions relating to some of the major volcanic events. Studies also revealed that the tephra accreted during the Agung (1963) and Krakatau (1883) eruptions harbored microbial cells (both coocoid and rods), suggesting that volcanic ash particles could provide a significant micro-niche for microbes and nanobes in the accreted ice (Laluraj et al., 2009). Microbiological studies of polar ice at different depths of the above ice core also provided an important comparison, as they preserve records of microbial cells and past climate conditions (Antony et al., 2012). The bacteria identified from the different depth of the ice core might have been transported and deposited into ice along with dust particles and marine aerosols.

The nitrate $\left(\mathrm{NO}_{3}^{-}\right)$profile of the IND-22/B4 core, which is considered to be a proxy for the zonal wind pattern over Antarctica, revealed synchronous changes in nitrate concentration with records of solar activity, showing relatively enhanced nitrate concentration during periods of reduced solar activity like the Dalton Minimum ( 1790-1830 AD) and Maunder Minimum ( 1640-1710 AD). The study suggest that the nitrogen species produced through processes such as solar activity, get associated with $\mathrm{nssSO}_{4}{ }^{2-}$ ions, get transported, deposited and preserved preferentially during very low temperature condition in Antarctica (Laluraj et al., 2011). The results revealed that multiple processes influenced its accumulation and preservation of nitrate $\left(\mathrm{NO}_{3}{ }^{-}\right)$at the study region. Correlation with the $\mathrm{nsSSO}_{4}{ }^{2-}$ records reveal that sulphate aerosols of major volcanic eruptions activated the production of nitric acid, thereafter scavenged by ion-induced nucleation and transported to polar ice sheets. The correlation between the nitrate and $\delta^{18} \mathrm{O}$ records further suggest 
a close link with the surface air temperatures, with lower temperature leading to higher nitrate preserved in the ice. Nitrate records preserved in the ice core appears to be influenced by production rates, processes in the atmosphere, as well as the temperature at the site of precipitation (Laluraj et al., 2011).

Application of the $\delta^{18} \mathrm{O}-\mathrm{T}$ spatial slope $(1.31 \%$ ol ${ }^{\circ} \mathrm{C}$ ) to the $\delta^{18} \mathrm{O}$ profiles of IND-25/B5 and IND-24/ B4 cores facilitated the estimation of surface air temperature in the study area (Naik et al., 2010 a \& b; Thamban et al., 2011 a \& b \& 2013). The oxygen isotope $\left(\delta^{18} \mathrm{O}\right)$ records of the IND-22/B4 core supported significant changes in temperature during periods of solar activity as well a warming trend of $2.7^{\circ} \mathrm{C}$ for the past 470 years, with an enhanced warming during the last several decades (Thamban et al., $2011 \&$ 2013). The SAT record of IND-25/B5 exhibited high amplitude oscillations, with an average warming of $1^{\circ} \mathrm{C}$ for the entire century (1905-2005) with a trend of $0.1^{\circ} \mathrm{C} / 10$ years. However, the data revealed greatly enhanced warming trend of $\sim 3^{\circ} \mathrm{C}$ during 1930-2005, with a warming of $\sim 0.4^{\circ} \mathrm{C} / 10$ years. Based on the available instrumental data, it was demonstrated that while the western and northern parts of the Antarctic Peninsula is significantly warming, the East Antarctica in general and the South Pole in particular has shown a small cooling (Turner et al., $2005 \& 2006$ ). Analysis of instrumental records from the coastal East Antarctic 'Novo' station also indicate a warming for the last $\sim 50$ years with similar temperature trend as found in the IND-25/B5 ice core (Naik et al., 2010 b). Further support for such a warming derive from another coastal ice core from DML, which estimates a positive trend of the order of $0.12 \%$ /decade for a similar time period (Divine $e t$ al., 2009). Therefore, both the instrumental data as well as the proxy records confirms a significant warming during the past century at coastal DML region.

\section{Antarctic Climate Variability and Its Linkages to SAM and ENSO}

The El Niño-Southern Oscillation (ENSO) is linked to the Antarctic system through the Pacific South American pattern (PSA), which represents a series of positive and negative geopotential height anomalies initiated from tropical convection and extending from central equatorial Pacific to Australia, South Pacific near Antarctica, South America and then bending northwards towards Africa (Turner, 2004). During the ENSO events, the PSA pattern gives rise to geopotential height anomalies over the AmundsenBellingshausen seas and the Weddell Sea region. Studies have revealed that the Southern Annular Mode (SAM) significantly influences the Antarctic climate (Kwok and Comiso, 2002). The SAM, a hemisphere-wide atmospheric pattern, contributes to $\sim 35 \%$ of variance in sea level pressure or geopotential height on a large range of time scales (Marshall, 2003). Several studies emphasised the crucial role of SAM on the recent climate changes across the Antarctic continent. Over the last 50 years, the SAM has shifted more into its positive phase with decreases of surface pressure over the Antarctic and corresponding increases at mid-latitudes (Marshall, 2003). The positive trend in the SAM seems to have resulted in a strengthening of the circumpolar westerlies and contributed to the spatial variability in Antarctic temperature change (Kwok and Comiso, 2002; Marshall, 2007). Most importantly, ENSO is also known to affect the SAM in a highly non-linear way. The two forcings can combine, partially offset or even enhance their influence on each other and the Southern Hemisphere as a whole (Gregory and Noone, 2008; Divine et al., 2009; Turner et al., 2009).

A detailed study was conducted on the regional atmospheric circulation changes associated with a reversal in the sign of the relationship between the SAM and near-surface temperatures in coastal parts of East Antarctica based on instrumental data from Halley station as well as an ice core from coastal Dronning Maud Land (Marshall et al., 2009). The study revealed that the key factor affecting the regional SAM-temperature relationship is the relative magnitude of two climatological low pressure centres to the west and east of the area, which determines the source region of air masses advected into the locality. By integrating the proxy temperature data using ice cores and various proxy records across seven continental-scale regions, a global study revealed an overall cooling trend across nearly all continents during the last two thousand years (PAGES $2 \mathrm{k}$ Consortium, 2013). This cooling trend was reversed by distinct warming, beginning in some regions at the end of the $19^{\text {th }}$ century. This cooling trend was reversed by distinct warming, beginning in some regions at the 
end of the 19th century.

In order to assess the temporal isotopic variability of ice cores as high-resolution quantitative proxy record of air temperatures and its relation to the southern hemispheric climatic modes, an ultra-highresolution (>12 samples per year) ice core record was analyzed in relation to instrumental records (Naik et al., $2010 \mathrm{a} \& \mathrm{~b}$ ). Comparison of the ice core $\delta^{18} \mathrm{O}$ record with the reconstructed index of SAM for the period 1905 to 2005 was made after a 4-year low pass filtering of both data. Such a filtering could take care of the well known 4-5 yr variability within the SAM data (Thompson and Wallace, 2000). Although the correlations are low $\left(\mathrm{r}^{2}=-0.01 ; \mathrm{p}=0.1\right)$, it is negative with high SAM corresponding to lower $\delta^{18} \mathrm{O}$ and vice versa (Naik et al., 2010 a). This suggests that higher polarity of SAM corresponds to lower temperatures and vice versa. This is a component of the opposite relationship driven by SAM on surface air temperature over the west Antarctica (Gregory and Noone, 2008) and east Antarctica. SAM is also known to play an important role in driving decadal temperature changes in the Southern Hemisphere. A running decadal correlation between the annual $\delta^{18} \mathrm{O}$ and SAM records also indicated an overall negative relationship, with certain periods (1918-1927; 19381947; and 1989-2005) showing absence of correlations or even weak positive relationships (Naik et al., 2010 b).

Relationships between the surface air temperature, SAM and ENSO in the study region were established using the ice core annual $\delta^{18} \mathrm{O}$ data, the reconstructed SOI as well as the SAM indices. The analysis showed that for the period wherein the $\delta^{18} \mathrm{O}$ and SAM relationship was insignificant or positive (1918-1927; 1938-1947 and 1989-2005), the relationships between the SOI and SAM are also inphase (Naik et al., 2010 b). Interestingly, the above periods (1918-1927; 1938-1947 and 1989-2005) incorporate several El Niño and La Niña years. When the years of El Niño and La Niña events are omitted from the records, the relationship between the filtered $\mathrm{d}^{18} \mathrm{O}$ and SAM data became statistically significant $\left(r^{2}=-0.2 ; p=0.02\right)$, suggesting that ENSO events weakens the SAM-temperature relationship during these periods (Naik et al., 2010 b). The results thus reveals that during the past century, the combined influence of ENSO-SAM modes have controlled the temporal changes in $\delta^{18} \mathrm{O}$ values at the core site.

The dust record of IND-25/B5 ice core showed that dust deposition in East Antarctica followed the Southern Hemispheric climate change and doubled during the $20^{\text {th }}$ century (Laluraj et al., 2014). Strong positive correlation observed between dust flux and the SAM suggests that the positive values of the SAM index are likely to be responsible for the recent increase in dust deposition over East Antarctica, through strengthening of westerly winds. The NCEP/ NCAR reanalysis data reveals that the polar easterlies consistently strengthened since 1985 at the study region, leading to the sinking of dust materials brought by the stronger westerlies. Interestingly, the timing and amplitude of the insoluble dust flux matched remarkably well with the trace metal fluxes of $\mathrm{Ba}$, $\mathrm{Cr}, \mathrm{Cu}$, and $\mathrm{Zn}$, confirming that dust was the main carrier of airborne geochemical tracers to East Antarctica in the recent past (Laluraj et al., 2014). The observed doubling of dust and associated trace metal deposition in East Antarctica have wide-ranging implications for understanding the factors driving the inter-continental transportation of impurities and their environmental impact on Antarctica. These results have far-reaching implications for understanding the changes in temperature and dust levels and their impact on climate both in the recent past and future.

High resolution study of deuterium excess (dexcess), sea-salt sodium (ss- $\left.\mathrm{Na}^{+}\right)$and methane sulfonic acid (MSA) in the ice core IND-25/B5 from coastal Dronning Maud Land also revealed the history of moisture transport and sea ice condition during the last century (Rahaman et al., 2016). Sea ice extent (SIE) in the Weddell Sea was reconstructed based on Antarctic ice core records of stable oxygen $\left(\delta^{18} \mathrm{O}\right)$, hydrogen $(\delta \mathrm{D})$ isotopes and sea-salt- $\mathrm{Na}^{+}$. Among them, ss-Na+ flux record shows significant positive relationship with winter SIE in the Weddell Sea. Wavelet analysis of SAM index and SOI shows the highest common power in 4-8 year band during 19401960 and 1990-2000 overlapping with the period of higher SIE. This shows large variability during the last century (1905-2005 AD) which impacted moisture transport from various oceanic sectors to Antarctica. Cluster of backward wind trajectories shows that air parcels were mainly originated from the Weddell Sea with additional sources from the Ross Sea and the Bellingshausen-Amundsen Sea regions. Dramatic 
increase in SIE was observed in the Weddell Sea sector during 1940-1980. This study suggests that moisture source and sea ice variability in annualdecadal scale in Antarctica seems to be largely influenced by SAM and its teleconnection to ENSO. Further, the multifaceted scientific studies being carried out by Indian scientists in the realm of ice core palaeoclimatic research will contribute significantly to the global community's ongoing efforts to better understand the past climate variability during the Holocene and its implication to the changing environment.

\section{Conclusions}

During the 2008-2016, the Indian scientists have used a variety of proxy climatic records on ice cores from East Antarctica. Among the diverse types of studies undertaken, the ice core studies have generated large amount of knowledge basis on the Antarctic climate and its global/regional linkages. Ice core proxy based reconstruction revealed that the estimated surface air

\section{References}

Antony R, Krishnan K P, Laluraj C M, Thamban M, Dhakephalkar P K, Anupama S and Shivaji S (2012) Diversity and physiology of culturable bacteria associated with a coastal Antarctic ice core Microbiological Res 167 372-380

Bromwich D H, Rogers A N, Kallberg P, Cullather R I, White J W $\mathrm{C}$ and Kreutz K J (2000). ECMWF analysis and reanalysis depiction of ENSO signal in Antarctic precipitation Journal of Climate 13 1406-1420, doi: 10.1175/15200442(2000)013

Dansgaard W (1964) Stable isotopes in precipitation Tellus 16 pp. 436-468.

Divine D V, Isaksson E, Kaczmarska M, Godtliebsen F, Oerter H, Schlosser E, Johnsen S J, van den Broeke M and van de Wal R S W (2009) Tropical Pacific-high latitude south Atlantic teleconnections as seen in $\mathrm{d} 180$ variability in Antarctic coastal ice cores Journal of Geophysical Research 114 D11112, doi: 10.1029/2008JD010475

Gregory S and Noone D (2008) Variability in the teleconnection between the El Niño-Southern Oscillation and West Antarctic climate deduced from West Antarctic ice core temperatures revealed significant warming during the past five centuries. The study also revealed the utility of shallow ice cores in reconstructing the past changes in major climatic modes like the El Niño Southern Oscillation (ENSO) and Southern Annular Mode (SAM).

\section{Acknowledgments}

Ministry of Earth Sciences (New Delhi) is acknowledged for the financial support. The author is grateful to the large efforts made by various scientists at National Centre for Antarctic and Ocean Research and Geological Survey of India to retrieve the ice cores and conduct painstaking analyses. Special thanks are to: Arun Chaturvedi (GSI), A. Rajakumar (IIT-Kharagpur), Prakash Shrivastava (GSI), Sushant Naik (NIO), C.M. Laluraj (NCAOR), Waliur Rahaman (NCAOR), K. Mahalinganathan (NCAOR), B. L. Redkar (NCAOR), and Ashish Paiguinkar (NCAOR). This is the NCAOR contribution No. 37/2016.

isotope records Journal of Geophysical Research 113 D17110, doi: 10.1029/2007JD009107

Jouzel J, Vimeux F, Caillon N, Delaygue G, Hoffmann G, MassonDelmotte V and Parrenin F (2003) Magnitude of isotope/ temperature scaling for interpretation of central Antarctic ice cores Journal of Geophysical Research 108, 4361, doi: 10.1029/2002JD002677

Kwok R and Comiso J C (2002) Southern ocean climate and sea ice anomalies associated with the Southern Oscillation Journal of Climate 15 487-501

Laluraj C M, Thamban M and Satheesan K (2014) Dust and associated geochemical fluxes in an ice core from the coastal East Antarctica and its linkages with Southern hemisphere climate variability Atmospheric Environment 90 23-32

Laluraj C M, Thamban M, Naik S S, Redkar B L, Chaturvedi A and Ravindra R (2011) Nitrate records of a shallow ice core from East Antarctica: atmospheric processes, preservation and climatic implications The Holocene 21 351-356

Laluraj C M, Krishnan K P, Thamban M, Rahul M, Chaturvedi A, Naik S S, D'Souza W, Ravindra R (2009) Origin and characterisation of microparticles in an ice core from the Central Dronning Maud Land, East Antarctica 
Environmental Monitoring and Assessment 149 pp 377383

Lefebvre W, Goosse H, Timmermann R and Fichefet T (2004) Influence of the Southern Annular Mode on the sea iceocean system Journal of Geophysical Research 109 C09005, doi:10.1029/2004JC002403

Marshall G J (2003) Trends in the southern annular mode from observations and reanalyses Journal of Climate 164134 4143

Marshall G J (2007) Half-century seasonal relationships between the Southern Annular Mode and Antarctic temperatures International Journal of Climatology 27: 373-383

Marshall G J, Battista S, Naik S S and Thamban M (2009) Analysis of a regional change in the sign of the SAM-temperature relationship in Antarctica Climate Dynamics DOI: 10.1007/ s00382-009-0682-9

Mayewski P A, Meredith M P, Summerhayes C P, Turner J, Worby A, Barrett P J, Casassa G, Bertler N AN, Bracegirdle T, Naveira Garabato A C, Bromwich D, Campbell H, Hamilton G S, Lyons W B, Maasch K A, Aoki S, Xiao C and Tas van Ommen (2009) State of the Antarctic and Southern Ocean climate system Reviews of Geophysics $\mathbf{4 7}$ pp RG1003 1-38

Naik S S, Thamban M, Laluraj C M, Redkar B L and Chaturvedi A (2010a) A century of climate variability in the central Dronning Maud Land, East Antarctica and its relation to Southern Annular Mode and El Niño Southern Oscillation Journal of Geophysical Research (Atmospheres) 115 D16102, doi: 10.1029/2009JD013268

Naik S S, Thamban M, Laluraj C M, Redkar B L and Chaturvedi A (2010b) A century of climate variability in central Dronning Maud Land, East Antarctica, and its relation to Southern Annular Mode and El Niño; Southern Oscillation Journal of Geophysical Research 115 D16102, doi: 10.1029/ 2009JD013268, 2010, 1-12

PAGES 2k Consortium (2013) Continental-scale temperature variability during the last two millennia Nature Geosciences $6339-346$

Rahaman W, Thamban M and Laluraj C M (2016) Twentieth Century sea ice variability in the Weddell Sea and its effect on moisture transport: Evidence from a coastal East Antarctic ice core record The Holocene 26 338-349

Schneider D P, Steig E J, van Ommen T D, Bitz C M, Dixon D, Mayewski P A and Jones J M (2006) Antarctic temperatures over the past two centuries, from ice cores
Geophysical Research Letters 33 L16707, doi: 10.1029/ 2006GL027057

Thamban M, Laluraj C M, Naik S S and Chaturvedi A (2011b) Reconstruction of Antarctic climate change using ice core proxy records from the coastal Dronning Maud Land, East Antarctica Journal of Geological Society of India 78 19-29

Thamban M, Naik S S, Laluraj C M and Ravindra R (2011a) High resolution reconstructions of recent warming using instrumental and ice core records from coastal Antarctica Mausam 62 665-672

Thamban M, Naik S S, Laluraj C M, Chaturvedi A and Ravindra R (2012) Antarctic climate variability during the past few centuries based on ice core records from coastal Dronning Maud Land and its implications on the recent warming. In: Earth System Processes and Disaster Management (Eds: R. Sinha and R. Ravindra) pp 239, Society of Earth Scientists Series, Springer, 2013, XII

Thompson D W J and Wallace J M (2000) Annular modes in the extratropical circulation. Part I: Month-to-month variability Journal of Climate 13 1000-1016

Trenberth K E, Jones P D, Ambenje P, Bojariu R, Easterling D, Klein Tank A, Parker D, Rahimzadeh F, Renwick J A, Rusticucci M, Soden B and Zhai P (2007) Observations: Surface and Atmospheric Climate Change. In: Climate Change 2007 - The Physical Science Basis. Contribution of WG1 to the Fourth Assessment Report of the Intergovernmental Panel on Climate Change. Cambridge University Press. Cambridge, U. K., and New York, NY, USA, 235-336

Turner J (2004) The El Niño-Southern Oscillation and Antarctica International Journal of Climatology 24 1-31, doi: 10.1002/ joc. 965

Turner J, Bindschadler R, Convey P, di Prisco G, Fahrbach E, Gutt J, Hodgson D, Mayewski P and Summerhayes C (2009) Antarctic Climate Change and the Environment: a contribution to the International Polar Year. Scientific Committee on Antarctic Research, Cambridge, ISBN 978$0-948277-22-1$

Turner J, Colwell S R, Marshall G J, Lachlan-Cope T A, Carleton A M, Jones P D, Lagun V, Reid P A, and Iagovkina S (2005) Antarctic climate change during the last 50 years International Journal of Climatology 25 279-294

Turner J, Lachlan-Cope T A, Colwell S, Marshall G J and Connolley W M (2006) Significant warming of the Antarctic winter troposphere Science 311 1914-1917. 